\title{
Fostering Saudi EFL Learners' Communicative, Collaborative and Critical Thinking Skills Through the Technique of In-Class Debate
}

\author{
Fahmeeda Gulnaz ${ }^{1}$ \\ ${ }^{1}$ English Language Centre, Deanship of Supportive Studies, Taif University, Saudi Arabia \\ Correspondence: Fahmeeda Gulnaz, Assistant Professor, English Language Centre, Deanship of Supportive \\ Studies, Taif University, P. O. Box 888, Taif 21974, Saudi Arabia. E-mail: fahmeedagulnaz@gmail.com
}

Received: June 3, $2020 \quad$ Accepted: July 20, $2020 \quad$ Online Published: July 30, 2020

doi:10.5539/ijel.v10n5p265 URL: https://doi.org/10.5539/ijel.v10n5p265

\begin{abstract}
Diverse learning styles of the learners require instructors to utilize wide variety of instructional strategies to engage their interest and motivation. In-class debate is a systematic instructional strategy utilized to bring the dynamics of social life into the classroom to cultivate learners' active-involvement in the content of the subject. It hones learners' range of skills, such as; oral-communication, social-interaction, critical thinking skills and internalization of the course content. For the purposes of present study, the researcher utilized qualitative cum quantitative research tools to collect the data from the participants. An opinionnaire with 14 items was developed with closed ended questions. The instrument was designed to measure four variables, which are tabulated into four sections (See tables 3-6): (a) in-class debate inculcates learners' collaborative, communicative and cooperative paradigms;(b) it triggers learners' complete mastery of the course content, i.e., retention, assimilation and understanding, coupled with boosts stack of skills involved in the process; (c) it fosters EFL learners' ability to critically evaluate and analyze everything; and (d) finally it focuses on learners' creative and critical thinking skills and make them active and independent pursuers of knowledge. The survey was administered to 87 female EFL learners of Taif University to identify the impacts of debate on their range of academic skills. The findings of the study indicate that in-class debate effectively generates learners' several skills since it targets their thinking skill, contemplation, reflection and ultimately stimulates their productive, receptive, analytical and critical thinking skills. Yet, more faculties can be activated and maximum results can be obtained, if this interactive strategy is implemented in a structured format with a properly designed rubric focusing on learners' specific skills.
\end{abstract}

Keywords: communicative and collaborative skills, EFL learners, fostering critical thinking skills, learning to think, through the technique of in-class debate

\section{Introduction}

Debate is inherently associated with the human life. The humans are persistently engaged in convincing and persuading to their fellow beings; either by extending competing arguments, endeavoring to resolve the conflicts, struggling to launch new laws/policies or trying to reinforce one's own view-point. In this context, the relation of debate to human life is the relation of part and whole as 'whole' cannot maintain its intactness without the presence of its 'several parts,' similar is the case with the part which loses its distinctness without being included in the whole or getting associated with other parts. Communication and interaction are the two indispensable constructs of debate and without them life of human beings seems difficult if not impossible. Debate can be formal and informal. Former is utilized by the law making bodies, in the parliament, court and media proceedings or in the competitions of academic settings whereas latter is casually practiced among colleagues or friends in everyday life. It's beyond doubt that individuals who can solve the problems, challenge assumptions, reasonably disagree on controversial issues, and vehemently question strange phenomenon are highly privileged in every walk of life.

The initial development of in-class debate took place in the 19th century. It started flourishing in the 1980s, when critical thinking is considered a compulsory skill to be taught in academic settings (Othman, Sahamid, Zulkefli, Hashim, \& Mohamad, 2015; Darby, 2007). The traditional teaching method focuses solely on lecturing and examination system; however, in-class debate chooses entirely different course of action and focuses on learners' active-engagement, complex thinking processes, retention of knowledge and mastery of the content 
(Roy \& Macchiette, 2005; Freeley \& Steinberg, 2005; Dobson, 1987). As an instructional tool, it involves learners in giving their view point from competing perspectives to rebut or refute opponents' arguments. It targets several faculties of the learners as findings of numerous studies indicate that it is very effective strategy to ingrain communicative, collaborative and critical thinking skill (Camp \& Schnader, 2010; Paul \& Elder, 2007; Ryan \& College, 2006; Roy \& Macchiette, 2005; Ng, Lan, \& They, 2004). The systematic presentation of competing arguments generate learners' oral communication, collaboration, ability to analyze, evaluate, create, and ultimately reinforce learners' critical thinking skills (Rudd, 2007; Kosciulek \& Wheaton, 2003; Hasibuan \& Batubara, 2012; Resnick, 1989; Lipman, 1988). Resnick (1989) highlights its importance by suggesting its inclusion as a foundational skill in the curriculum instead of being taken as an insignificant sub-skill.

By keeping in view the importance of critical thinking skill, several universities of Saudi Arabia have incorporated it in their curriculum and one among them is Taif University, KSA. In every unit of UNLOCK - book used for IEAP courses (Intensive English for Academic Purposes) - Bloom's learning objectives have been incorporated. In addition to this, one entire section of each unit has been allocated to the critical thinking in the books of reading \& writing and listening \& speaking skills.

The researchers of different disciplines have undertaken several inquiries in the field of in-class debate to investigate its historical background, development and correlation with learners' academic skills. These studies explore numerous dimensions of in-class debate and its impacts on range of learners' skills and abilities. Some of the empirical studies in the field of in-class debate include; Kennedy (2007); Zare \& Othman (2013); Iman (2017); Salim (2015); and El Majidi (2015). In the context of critical thinking as an off-shoot of in-class debate several studies have been carried out in different universities of Saudi Arabia, hence, few among them are discussed below:

1) So far, in Saudi Arabia several studies have been conducted in the field of critical thinking to investigate its promises, perils and impacts on learners' multiple academic skills. Among them the research of Al Zahrani and Elyas (2017) highlights promises and challenges of utilizing activities that foster critical thinking skill of the English as foreign language (EFL) learners. The research has been conducted at King Abdulaziz University, Jeddah, Saudi Arabia. In addition to this, the study investigates the concept of critical thinking from Islamic and Western perspectives and identifies the possible barriers which hinder promotion of $\mathrm{CT}$ in the classrooms. Finally, the researchers suggest using of strategies to inculcate critical thinking skills of Saudi EFL learners.

2) Similarly, the work of Allamnakhrah (2013) reinforces the importance of the practice of critical thinking skill by the Saudi learners at educational institutions. His qualitative empirical study investigates learners' perceptions about their learning experiences of critical thinking in secondary pre-service teacher education program at King Abdul Aziz University and Arab Open University, Saudi Arabia.

3) In a similar vein, Alsaleh's (2020) work aims to review the existing literature, which has been conducted to recognize the need of the incorporation of activities related to the critical thinking in the curriculum. Alsaleh suggests the use of critical thinking in teaching approaches as well as its gradation for all levels of learners. The findings reflect a gap in the teaching of CT skills and the use of new technology at university.

4) By the same token, Gashan (2015) undertakes an inquiry to investigate Saudi pre-service teachers' knowledge about critical thinking and its utilization in different activities in the classroom. The findings of the study indicate that pre-service teachers have inadequate knowledge and understanding about critical thinking skill. The study recommends the need for professional development programs to enhance necessary skills of the pre-service teachers to promote critical thinking in teaching and learning process.

5) Furthermore, the study of Alwadai (2014) examines Islamic teachers' perceptions about the improvement of critical thinking skills of the learners at elementary schools in the Southwestern province of Saudi Arabia. The research finds several major barriers which hinder practice and improvement of critical thinking at elementary schools. The researcher recommends investigation of female Islamic teachers regarding the same subject matter to identify similarities and differences in the perceptions of male and female teachers.

6) Yet, another research has been conducted by Alwehaibi (2012) to investigate the effects of proposed critical thinking program on the development of critical thinking skill of the college students at Princess Noura Bint Abdulrahman University, Riyadh, Saudi Arabia. The study suggests a framework to design teaching methods that would help in developing the critical thinking skills of the college students.

The previous inquiries in the context of critical thinking skills and its importance for Saudi EFL learners were carried out at different universities of Saudi Arabia but until now no study has been undertaken to explore in-class debate and its impacts on learners multiple language skills, oral-communication, social-interaction, 
mastery of the course content and critical thinking skills at Taif University, Saudi Arabia.

\subsection{Statement of the Problem}

Nancy Tumposky (2004) identifies four flaws of in-class debate and question that whether it is a practical instructional strategy to inculcate variety of academic skills of the learners. She believes that in-class debate: (1) tends to fortify bipolar views, i.e. yes or no (affirmative or negative) on any given topic instead of producing multiple arguments or assumptions on the topic; (2) reinforces the belief of win or lose for the two parties in the competition; (2) inclines to justify two contending groups on any particular topic; (4) likely to incite confrontational environment in the classroom. Therefore, an inquiry about the opinions of the EFL learners of Taif University, who are the key stake holders in the teaching-learning process, is indispensable to assess and evaluate the effectiveness of in-class debate on the development of their critical thinking skill and numerous other academic skills.

\subsection{Research Objectives}

This empirical study has the following research objectives. The aim of the study was to:

a. trigger Saudi EFL learners' confidence to communicate, and collaborate persuasively coupled with take responsibility of their own learning through active collaboration and novel discussions;

b. enhance Saudi EFL learners' mastery of the course content, i.e. retention, assimilation and understanding;

c. develop Saudi EFL learners' ability to analyze, evaluate, create and think critically.

\subsection{Research Questions}

The following research questions have been envisaged for this empirical study:

1) How does in-class debate play a pivotal role in the development of learners' critical thinking skill?

2) How does in-class debate trigger learners' collaborative and communicative faculties?

3) What is the significance of in-class debate on EFL learners' mastery of the course content?

\section{Literature Review}

In-class debate nurtures learners' analytical skills, oral-communication, social-interaction, ability to synthesize the arguments, speak impromptu, and make informed decisions and judgments based on facts and authentic resources. The researchers who advocate the use of in-class debate believe that it gives the learners superior access to the content of the topic. These scholars claim that debate has the aptitude of promoting learners' competence and in-depth knowledge of the content of the subject (Doody \& Condon, 2012). The diligent exploration of several studies reveals strong association between in-class debate and the development of critical thinking. The context(s) of these undertakings report that in-class debate has the potential to foment learners' critical thinking and numerous other academic skills (Gaskaree, Mashhady, \& Dousti, 2010; Heining- Boynton \& Heining-Boynton, 1992; Hoch \& Hart, 1991; Rojas, 2001; Williams, Lively, \& Harper, 1994). Osborne (2005) contends that in order to substantiate a position in a debate, learners must go beyond the rote learning and start to think analytically and critically. Moreover, they must use reason to recognize delusions and "clearly establish the elements that justify or weaken their own points of view" (Alén et al., 2015). In-class debate improves learners' oral-communication skills and motivates them to think about not only the types of arguments but also the way to communicate those arguments. Cordon $(1988$, p. 23) illustrates correlation between verbal-interaction and analytical skills in these words that verbal-communication is: "a personal contribution that we make to the development of our own analytic competence". In the context of impacts of in-class debate on learners' academic skills Newmann \& Wehlage (1995, p. 8) report findings of the 'Center on Organization and Restructuring of Schools' that students' success is considered up to the mark when they are able to: "express the results of their disciplined inquiry in written, symbolic, oral discourse and in performances for audiences". Similarly, in-class debate hones learners' listening comprehension in order to extend powerful rebuttals to the opposing debaters. In this context, Snider \& Schnurer (2002) mention saying of one of their students, who states that in-class debate changed his life as it taught him not only to communicate effectively but also to listen others with great attention. In addition to the development of oral communication, debate enables the learners to internalize chunks of information for a longer period of time because they learnt that knowledge through debate and discussion. In a similar vein, Tumposky (2004) observes that exchange of arguments, retention and assimilation of information stimulates learners' cognitive development.

The instructors utilize in-class debate in educational settings to engender learners' range of skills, as for instance; ability to communicate, collaborate, do research, collect evidence and reasoning, analyze and evaluate materials, 
express competing perspectives with the objectives to contradict opposing arguments. In-class debate is appreciated widely by the learners and incorporated by the instructors in different academic scenarios to heighten understanding of the content through fun and competition. For the purposes of present study, the data was collected from 79 female EFL learners of Taif University to investigate their perceptions about the impacts of debate on their several academic skills coupled with deep understanding of the course content. The next sections have been given over to the several variables investigated in the present study.

\subsection{In-class Debate Fosters Collaborative Learning}

Collaborative learning is an umbrella term for variety of instructional strategies, such as pair work, group work, role plays, debates and discussions utilized to initiate interaction among the learners. Alder (1982, p. 50) associates in-class debate with active learning, "All genuine learning is active, not passive. It is a process of discovery in which the student is the main agent, not the teacher". In this context, Bartlett \& Ferber (1998) observe (Cited in Brownson, 2013) that the interactive and collaborative process of in-class debate is considered to be more effective than traditional teacher centered classrooms. Similarly, Oros (2007) expresses that in-class debate is intrinsically connected with the collaborative learning and critical thinking emerges as an offshoot of it. In a similar vein, Frijters et al. (2006) comment that the process of expressing thoughts and furnishing "for and against" arguments in a debate encourages interaction among the learners.

Bonwell (1996) states that active learning enhances learners' interest to analyze, synthesize and evaluate the arguments. Malone and Michael (2018) observe that generally in-class debate is categorized as a kind of collaborative learning, whereas, few scholars named it cooperative learning. However, both the terms can be used interchangeably for each other in the meaning of a technique that encourages learners to work together in a team. The collaborative techniques promote learners ability to take responsibility of their own learning and retain knowledge and information. Jagger (2013, p. 39) explains that: "classroom debate as a powerful learning tool for promoting classroom interaction and the development of skills such as communication, argument - construction, discussion and critical analysis". Furthermore, several scholars perceive that debate is: "a way to engage students in their own learning" (Moore, Clements, Sease, \& Anderson, 2015, p. 240).

In the context of in-class debate's contribution to learning, Malone \& Michael (2018) discuss that through this interactive strategy learning takes place in several ways. These modes include learners' motivation and interest towards the subject (Carroll, 2006), maximum classroom participation and interaction (Elliot, 1993), polish communicative enterprise (Kennedy, 2007) and as an end-product instill critical thinking skill (Landrum, 1991; Parcher, 1998; Roy \& Macchiette, 2005; Tessier, 2009; Wiggins \& Forrest, 2005; Kennedy, 2007). Kegley (2014, 1) takes it as an effective learning technique and highlights that: "debates enable students to develop team skills". He adds that the core idea working behind the use of in-class debate in higher education is to boost learning process and enhance collaboration between individuals and groups. Therefore, Jackson (2009, p. 253) elaborates that: "debate is not intended to be an end in itself, but rather a means to desirable educational outcomes that complement other teaching techniques and student experience". Therefore, in-class debate is a crucially significant strategy used to promote students' ability to think critically, solve problems, collaborate and communicate effectively.

\subsection{In-class Debate Cultivates Critical Thinking}

Critical thinking is related to the cognitive processes where learners, 'learn to think' and 'think about thinking'. Teaching critical thinking skill has become an increasing interest for the academicians in educational settings. They believe that critical thinking is crucially important in the development of learners' cognitive and other complex thinking processes. In recent years, it is perceived as one of the essential sub-competencies of 21 st century skills. Sternberg (1986, p. 3) explains critical thinking from the psychological cognitive perspective that: "the mental processes, strategies, and representations people use to solve problems, make decisions, and learn new concepts". Similarly, Ennis (1993, p. 180) defines CT: "reasonable reflective thinking focused on deciding what to believe or do". In a similar vein, Norris (1985) explains critical thinking as deciding logically what to or what not to believe. Both the researchers perceive that critical thinking is about being very cautious and reflective when taking decision to believe or do something. Gieve (1998, p. 126) brings to the fore that for learners to think critically they must be able to, "examine the reasons for their actions, their beliefs, and their knowledge claims, requiring them to defend themselves and question themselves, their peers, their teachers, experts, and authoritative texts". Kennedy (2007, p. 184) believes that frequent use of in-class debate boosts learners critical thinking skill, as for instance; “...defining the problem, assessing the credibility of sources, identifying and challenging assumptions, recognizing inconsistencies and prioritizing the relevance and salience of various points with the overall argument". Scannapeico (1997, p. 955) acknowledges significance of this 
innovative cum interactive strategy in these words: "Active learning fosters complex thinking processes and improves retention, assimilation, understanding, and proper application of course content". In this context, Nisbett (2003, p. 210) states, "Debate is an important educational tool for learning analytic thinking skills and for forcing self-conscious reflection on the validity of one's ideas." Zare \& Othman (2013) highlight broader perspectives of using in-class debate in the classroom. They believe that in-class debate develops learners' ability to handle social problems, and adjust them, understand diverse point of views and help in learning multiple dimensions of a single topic.

Munakata (2010) (Cited in Yang \& Rusli, 2012) believes that in-class debate enhances learners' interest in the subject matter of the content. The application of such activities enables learners to contemplate, understand, analyze and evaluate the topic in-depth and ultimately reflect with logically developed arguments (Chance, 1986). Similarly, Kennedy (2009) states that learners take in-class debate as an active and novel teaching strategy. In this regard, Freeley \& Steinberg (2005) (Cited in Kennedy, 2007) contend that for over two centuries: "academic debate has been recognized as one of the best methods of learning and developing critical thinking skills". In the process of preparation, learners explore numerous resources and materials which expose them to the wider perspectives. Contrary to this, Oros (2007) declares that in-class debate diverts learners' attention because it requires them to browse several search engines and probe into different resources which waste their time. For this reason they couldn't focus much on their recommended syllabus. By the same token, Zare \& Othman (2013), note that some of their learners have shown their dissatisfaction towards the use of debate for developing critical thinking skill. However, majority of the researchers show their strong inclination towards the use of in-class debate in the classroom and vehemently emphasize that this interactive strategy should be embedded in the curriculum as it is a viable means of developing effective learning experiences of the learners.

\subsection{In-class Debate Promotes Oral Communication Skills}

For a successful in-class debater, it is important to be confident, collaborative, possess sufficient mastery of the language skills and a good communicator of information. Paulette \& Wolf $(2000,176)$ discuss nature of in-class debate that it: "[...] is a speaking situation in which opposite point of views are presented and argued". Likewise, Combs \& Bourne (1994) observe that in-class debate targets diverse skills as it does not only cultivate learners' critical thinking skills but also ignite their collaborative and oral skills. Similarly, Roy \& Macchiette (2005) express the same idea and highlight that in-class debate is a bipolar activity and at one pole it teaches what to say and at another pole fosters the ability how to say it. Its multidimensional features improve learners' numerous academic skills: "Debating is the ultimate multi-task school activity since it involves research, writing, speaking, listening, and teamwork" (Allison, 2002, p. 13). Dundes (2001) investigates business leaders and reports that graduate students do not possess adequate oral communication skills. By the same token, Cronin \& Glenn (1991) reports that students of non-speech major cannot polish and develop their oral communication except those who specialize in the subject of communication or social relationship. These students should get an opportunity to take at least one course that emphasizes on oral communication. Steinfatt (1986) discusses that incorporation of activities that focus on speaking and interaction in various courses across the curriculum inculcate change in learners academic skills in several dimensions; where at one extreme they increase students' oral communication and at another extreme enhance expertise of their discipline-specific subjects.

McGee, \& Worth (2001) organize competitive debates among 286 competitors at 70 universities. The findings of their study indicate that debate enhanced learners' communicative proficiency. In a similar vein, Combs \& Bourne (1994) investigated in-class debate competition of marketing students and found improvement in their communicative skills. In-class debate also engenders empathy, social responsibility and in-depth mastery of the subject matter. In-class debate inculcates empathetic feelings to support both sides of the participants which reduce learner's bias towards opponent pair of debaters (Schroeder \& Ebert, 1983). In this context, Berdine (1987) points out that by defending both sides of a controversial topic, students become more open-minded as speaking in favour of an opposite position would temporarily takes them beyond their own bias, therefore; better able to see another person's perspectives. Williams, Doody \& Condon (2012) mention some additional benefits of in-class debate that it enables the learners to take responsibility of their own learning and help develop their soft skills, like; writing skill and team work which are highly appreciated in job perspectives.

\subsection{In-class Debate and Mastery of the Course Content}

Learners generally report enjoying in-class debate because they create the course content personal to defend their own view point ((Lantis, 2004). Freeley \& Steinberg $(2008$, p. 4) perceive debate as, "the process of inquiry and advocacy, a way of arriving at a reasoned judgment on a proposition". This involves the process of accepting different point of views and developing new understanding. According to Snider \& Schnurer (2006) it works like 
an event of collaborative competition, which is executed in verbal or written mode. It has been perceived by different scholars as an effective pedagogical devise that enable learners to take part in different activities and involve them to practice four language skills (Alasmari \& Ahmed, 2013; Lieb, 2007; Rybold, 2006). It is the tool that gives practice to the learners to experience linguistic input and output. In addition to this, it permits learners to accept the intellectual challenges of opponents and outperform each other in their arguments. The competition among the participants pushes them to think and reflect beyond the limit. Rowland (1995, p. 108) explains it in these words, "The competitive process pushes students to excel". Lieb (2007) adds to this that in competitive environment learners brush up their reasoning abilities and language proficiency. Mitchell $(1998$, p. 50) observes that, "... contest round competition is a powerful motivating force that draws in novices and pushes advanced debaters to dizzying heights of professional and academic excellence". The observation of Lewin \& Wakefield (1983, p. 116) in their psychology course at California State College is very significant to support the results of present study. Both the instructors debated each other in front of their students and finally concluded: "Although both of us had taught similar material in the past, the debates forced us to re-read and re-think both our own and the opposing position more intensely than is necessary to repeat lecture material". With reference to their experiment, Parcher (1998) contends that these professors needed to prepare more in-depth for the debate than their everyday lectures, the same analogy can be applied on the learners that they require to master the course content more deeply for the competition than for any other activity.

Hill (1982) expresses that most crucial incentive in the use of in-class debate is the fun and enjoyment which learners experience during the process. In this context, the results of several other studies also indicate that this activity provides great fun and intellectual educational experiences to the learners (Alford \& Surdu, 2002; Fallahi \& Haney, 2007; Omelicheva \& Avdeyeva, 2008; Woude, Janssen, \& Sanders, 2011). In a similar vein, some researchers investigate the significance of in-class debate as a teaching strategy (Alford \& Surdu, 2002; Kennedy, 2009). In this context, Stewart \& Pleisch (1998) highlight that more than $80 \%$ of their students have rated debate as the best strategy during a survey from 1994 to 1998. They mention that during these years not even a single student has shown any negative reaction against in-class debate. Khan, Omar, Babar \& Toh (2012) surveyed students of Health Economics in which the participants were divided into active debaters and non-active debaters. They investigated students' perception about in-class debate as a teaching strategy before and after the debates. The results show that learners reported positively towards not only increase in their knowledge but also interest and curiosity. Similar kinds of results are found in the study of Kennedy (2009) which show that majority of the participants not only have indicated their satisfaction towards the debate but also perceived it as a dynamic instructional tool.

\subsection{The Debate about Debate}

The history of debate can be traced back to Protagora Abdera in Athens (481-411 B.C), who has been considered as the father of debate (Huryn, 1986; Combs \& Bourne, 1994; Snider \& Schnurer, 2002; Freeley \& Steinberg, 2005). Many scholars acknowledge that in-class debate focuses on range of academic skills of the learners, such as verbal-communication, social responsibility and critical thinking including their deep insight of the course content (Kennedy, 2007; Zare \& Othman, 2013; Combs \& Bourne, 1994). Mercadante (1988, p. 1) expresses that in-class debate prepares powerful minds: "Perhaps one of the best ways we as instructors can help the minds of others to learn is to allow those minds to exercise their own powers through debate". It involves the learners in the content of their study material: "actively, broadly, deeply and personally" (Zare \& Othman, 2013, p. 1507). Krieger (2005) mentions that in-class debate engages learners in linguistic and cognitive interaction and enhances their language proficiency. By the same token, in-class debate inculcates learners' reading skill because in order to extend arguments learners need to read enough material to collect relevant evidence and resources, which certainly gives them exciting and valuable experiences.

Halvorsen (2005) suggests that debate enables the learners to investigate diverse aspects of an issue and enhances their ability to interact not only with their human counterparts but also with the content of the topic. Jackson (2009, p. 253) believes, "debate is not intended to be an end in itself, but rather a means to desirable educational outcomes that complement other teaching techniques and student experience". Bonwell \& Eison (1991) (Cited in Kennedy 2007, p. 183) discuss that debate provides active involvement to the learners in the course content and they: "...learn more effectively by actively analyzing, discussing, and applying content in meaningful ways rather than by passively absorbing information". Those who learn to debate well, learn how to develop constructive arguments for meaningful and persuasive presentation. In-class debate builds learners' tolerance, patience and the spirit of sports man-ship as debaters learn to defend their own viewpoint through listening, accepting or rebutting the opponents' perspectives. 


\subsection{Patterns of Debate}

For a successful debate, it is indispensible that it follows a specific procedure and organized format so that it can be conducted in an enthusiastic environment. The selection of well-developed model provides an opportunity to the participants to confidently share their knowledge and information with each other and consequently, rebut or accept their opponents' view point by following a specific pattern and thinking framework.

According to sociocultural researchers, second or foreign language acquisition can be effectively internalized through social interactive activities. Ohta (1995) expresses that when learners interact with each other and able to pool their knowledge in group discussion; they create greater knowledge and expertise than working individually. Pajoohande (2001) discusses that debate in groups is an effective strategy that exposed learners to multiplicity of ideas and arguments during discussion and collaboration with other group members. In everyday class, teachers use the technique of brainstorming to open up discussion for plurality of responses; thereupon, debate too provides opportunity to foster thinking skill, contemplation and reflection of the learners. Rahimi (2009) believes that curiosity plus group debate inculcate learners' communication skill and social relationship among the learners (Pajoohande, 2001), self-esteem and confidence of the learners. These patterns if implemented successfully would not only internalize topic of the debate but also reinforce understanding of the taught material Likewise, Lantolf (2002) discusses that learners construct their expertise in dialogic interaction, when they collaborate and share their learning goals to solve language problems.

Derouiche (2019) draws on the work of Kennedy (2007) and expresses that debate can be organized in different formats where all the students can show full involvement and demonstrate their expertise on the subject matter. However, selection of the format depends on the objectives of any given course as for instance; four-corner debate, fishbowl debate, Lincoln-Douglass Debate and the Role-Play Debate. To be more elaborative, Kennedy (2007) provides some formats of debate such as, Four-Corner debates, Role-Play debates, Fish-Bowl debate, Think-Pair-Share debates and Lincoln-Douglas debate which is further divided into Meeting-House and Problem-Solving debate. Beck (1999) reports that the assessment used in 'Problem-Solving debate', warrants active-engagement of all the learners because debaters are evaluated by rest of the students as well as it requires non-debating students to write summary of the arguments extended by both the sides.

\subsection{Problem-Solving Debate Model}

For the purposes of this study, researcher has utilized problem-solving debate format and created 11 groups, each containing eight participants $(\mathrm{n}=8)$ to develop their communicative, collaborative, content mastery and critical thinking skill. Huryn (1986) observes that in this format 1st pair of speakers give definition, explanation and background information about the topic, the next set of speakers furnish for and against arguments about contention-1 plus reasoning and evidence, similarly the 3rd pair of speakers provide for and against arguments about contention-2 plus evidence and logical reasoning, finally, 4th pair of speakers discuss the need of a plan for the problem, how to resolve it, summary of the position of each team and provide final conclusion.

Table 1. In-class debate: problem solving model

\begin{tabular}{ll}
\hline Thinking Framework & \\
\hline Topic of debate: & $\begin{array}{l}\text { Outline the human causes of climate change. What effects will } \\
\text { these have on the planet? }\end{array}$ \\
\hline Definition and Explanation of the Topic: & 2 learners: 1st provides definition + 2nd gives explanation \\
Contention 1: Evidence + Reasoning & 2 learners: 1 st for + 2nd against \\
Contention 2: Evidence + Reasoning & 2 learners: 1st for + 2nd against \\
Need or lack of need for planning & 2 learners: 1 st for + 2nd against \\
How your plan will help resolve the problem? & \\
Conclusion + Sources/References & \\
\hline
\end{tabular}

\subsection{The role of Audience Learners (non-debaters)}

The researchers have suggested different activities for the audience learners to make the whole debate process a dynamic paradigm. In this context, Snider \& Schnurer (2002) require that during in-class debate audience learners should reduce notes into writing, whereas Moeller (1985) directs to each audience student to submit a 250-word passage defending either the negative or positive perspectives shared by each side of the contestants. Similarly, Temple (1997) asks learners to summarize the arguments used by both the sides, and Landrum (1991) guides the learners to submit summary of the arguments extended by set of pair and provide evidence to support 
their position. Yet, Huryn (1986) suggests adding debate material in exam while Scannapieco (1997) asks non-debating learners to create multiple choice questions after each debate which thenceforth can be used in exam (Cited in Kennedy, 2007).

\section{Method}

\subsection{Research Design}

The present empirical study investigated eighty-seven $(n=87)$ Taif University's female EFL learners to seek their perceptions about the impacts of debate on their collaborative, communicative, content mastery and critical thinking skills. The survey was designed to conduct descriptive research in which perceptions of the participants were recorded and quantitatively analyzed to present the findings of the present study.

\subsection{Participants}

The present study utilized random sampling approach to generate the data. Arabic version of the opinionnaire was administered to the randomly selected eighty-seven $(n=87)$ female EFL learners of Taif University.

\subsection{Instrumentation}

The researcher has browsed and studied numerous similar context(s) to develop appropriate tool to gather opinions of the participants through the survey (See for example Scott, 2008; Kennedy, 2009; Iman, 2017; Zare \& Othman, 2013; Darby, 2007; Salim, 2015; Derouiche, 2019; \& El Majidi, 2015). A 14-item Likert-scale opinionnaire was designed with closed ended statements. This empirical study set-forth three research questions in connection with the fourteen items raked in the four tables.

\subsection{Validity and Reliability}

The initial version of the survey along with its Arabic translation was sent to two experienced professors at Taif University to check face and content-validity of the tool. The feedback received from them was immediately incorporated in the survey and henceforth modified version of the opinionnaire was pilot-tested with 18 English language teachers from the same context. The data generated through the pilot test was entered manually and Cronbach's Alpha reliability test was run to determine reliability of the instrument. The results have indicated an acceptable level of reliability of .771. The final version of the opinionnaire was administered to the participants to collect the data.

Table 2. Reliability coefficient

\begin{tabular}{ll}
\hline Number of Cases & 18 \\
Number of Items & 14 \\
Alpha & .771 \\
\hline
\end{tabular}

The findings of George and Mallery (2003, cited in Javid \& Umer, 2014) report that alpha coefficient of more than .70 is acceptable for reliable scientific investigation.

\subsection{Data Collection}

The researcher followed a standardized procedure to determine the validity and reliability of the instrument. The final version of 14-item strongly-agree to strongly-disagree likert scale opinionnaire was administered to the randomly selected eighty-seven $(\mathrm{n}=87)$ female EFL learners of Taif University. The research tool was translated into Arabic by keeping in view the fact that opinionnaire items in English might hinder understanding of the participants. Arabic version of the research tool has distributed to the participants of this empirical study to generate the data. Therefore, the researcher received only seventy-nine $(n=79)$ valid responses from the participants. In addition to this, the researcher has developed an interview with six open-ended questions to collect the data from four male $(n=4 M)$ and three female $(n=3$ F) EFL teachers of Taif University. The interview was conducted to cross examine perceptions of the participants of the opinionnaire. The identity of the seven interviewees (ELC teachers) was kept anonymous in order to avoid future complications. However, they have been assigned different codes, as for instance; Instructor-1, Instructor-2, and Instructor-3, so on and so forth.

\subsection{Data Analysis}

The data collected through 79 valid responses of the participants was coded, manually entered and descriptively analyzed in terms of means, range and standard deviation by using version 23 of Statistical Package for Social Sciences (SPSS). The items with higher the mean value means higher the preference attached by the participants. 
The descriptive statistics of data was raked in the tables to analyze and discuss with the help of the findings of previous studies in the section of "results and discussion".

\section{Results and Discussion}

This section displays the results related to the data generated from the participants' responses and rakes it in the four-tables. Moreover, the findings of the present empirical study are discussed and supported with the results of previous context(s) and undertakings.

Table 3. Saudi EFL learners' opinions about the impacts of in-class debate on the mastery of the course content

\begin{tabular}{|c|c|c|c|c|c|c|c|c|}
\hline S. \# & Statements & Gr. & $\mathrm{N}$ & Range & Min. & Max. & Mean & SD \\
\hline 1. & $\begin{array}{l}\text { The new knowledge which I learnt from the topic debated } \\
\text { helped me to recall my previous knowledge. }\end{array}$ & $\mathrm{F}$ & 79 & 4.00 & 1.00 & 5.00 & 4.3924 & 1.01801 \\
\hline 2. & $\begin{array}{l}\text { The information collected through debate helped me to } \\
\text { connect new chunks of information with my existing } \\
\text { knowledge as well as assimilate and retain them in a better } \\
\text { way. }\end{array}$ & $\mathrm{F}$ & 79 & 4.00 & 1.00 & 5.00 & 4.4510 & .93091 \\
\hline 3. & $\begin{array}{l}\text { In-class debate stimulated me to gather new information and } \\
\text { knowledge and in this process developed my in-depth } \\
\text { understanding of the topic debated. }\end{array}$ & $\mathrm{F}$ & 79 & 4.00 & 1.00 & 5.00 & 4.4871 & 1.01098 \\
\hline
\end{tabular}

Table 3 details descriptive statistics of the responses of 79 female EFL learners about the impacts of in-class debate on their mastery of the course content. The results of three items reveal that participants of this study highly satisfied with the positive impacts of in-class debate on their in-depth understanding of the course content. All the raked items received high mean value of more than four. The highest mean value of (mean=4.48) is assigned to the item 3, which states that in-class debate enables the learners to collect new information and knowledge and deepen their understanding of the subject matter. Combs \& Bourne (1994) (Cited in Kennedy, 2007) surveyed a senior-level marketing course where $78 \%$ of 544 students stated that they learnt better through in-class debate than traditional lecture method.

Item 2 elicits participants' belief that in-class debate helps them to connect new chunks of information with their prior knowledge coupled with fosters their assimilation and retention of knowledge. The item received high mean value of (mean=4.45), which indicates learners' maximum choice for the concept discussed in the statement. Schroeder \& Ebert (1983) count enormous benefits of debates on students' learning experience. They declare that this approach accelerates learners' curiosity to learn, enhance their mastery of the course content and develop research skill, interaction, empathy and oracy. Similarly, Zare \& Othman $(2013,2)$ discuss that: "debate encourages students to learn course content better, since they are engaged in it [sic] actively, broadly, deeply and personally". In this backdrop, instructor-1 points out that: "Debate needs a lot of brainstorming and homework because the participants are constantly challenged through opposing and arguing a point of view of the interlocutor(s). This process beyond any doubt helps connect participants' background knowledge and the new relevant information." Similar kind of findings are traced back in the work of Walker \& Warhust (2000), who hold that debates enable the learners to connect new chunks of information with their previous knowledge. The findings of their study indicate that $82 \%$ of the students claim that they understood the subject matter very well whilst $85 \%$ acknowledged that through debates they learned something really significant.

The 3rd most-favored item in this cluster with mean value of (mean=4.36) remains statement 1 . It expresses the idea that during the preparation of debate learners recall their previous knowledge on the subject matter through brain-storming. The findings of the study of Kennedy (2009) indicate that students perceive debate as an innovative teaching technique, which enables the learners to browse and collect information from different resources and broaden their perspectives. In a similar vein, Zare \& Othman $(2013,2)$ express that: "debate encourages students to learn course content better, since they are engaged in the course content actively, broadly, deeply and personally". Snider \& Schnurer (2002) discuss that debate engages learners in active learning and enable them to become independent and autonomous learners. In addition to this, Munakata (2010) mentions that in-class debate enhance learners' motivation and curiosity about the content of the subject matter. In this backdrop, instructor-4 mentions that: "If topic of the debate has already been predetermined and announced then the participants try their level best to collect maximum new, suitable and appropriate information. Secondly, acceptance and denial of others' idea is part and parcel of a debate. Debates develop open mindedness of the learners. "The participants' perceptions for the three items displayed in the table reveal learners positive reaction 
towards the in-class debate. They strongly acknowledge that debate actively engages them in defensive and offensive arguments that result in the mastery of the course content.

Table 4. Saudi EFL learners' opinions about the impacts of in-class debate on their collaborative and communicative skills

\begin{tabular}{|c|c|c|c|c|c|c|c|c|}
\hline S. \# & Statements & Gr. & $\mathrm{N}$ & Range & Min. & Max. & Mean & $\mathrm{SD}$ \\
\hline 4. & $\begin{array}{l}\text { The in-class debate promotes collaboration and } \\
\text { teamwork by engaging the learners in discussions. }\end{array}$ & $\mathrm{F}$ & 79 & 4.00 & 1.00 & 5.00 & 4.4177 & .87130 \\
\hline 5. & $\begin{array}{l}\text { The debate process reduces bias and promotes } \\
\text { acceptance of opponents and other debaters' } \\
\text { perspectives. }\end{array}$ & $\mathrm{F}$ & 79 & 4.00 & 1.00 & 5.00 & 4.2911 & .98907 \\
\hline 6. & $\begin{array}{l}\text { I felt confident by explaining my topic, developing } \\
\text { arguments, providing evidence and reasoning for it. }\end{array}$ & $\mathrm{F}$ & 79 & 4.00 & 1.00 & 5.00 & 4.2911 & .86457 \\
\hline 7. & $\begin{array}{l}\text { In-class debate reinforces active learning by giving the } \\
\text { learners control on their own learning. }\end{array}$ & $\mathrm{F}$ & 79 & 4.00 & 1.00 & 5.00 & 4.3544 & .80125 \\
\hline
\end{tabular}

Table 4 contains the results generated by the descriptive analyses of four items related to learners' opinions about the impacts of debate on their collaborative and cooperative skills. The highest mean of (mean=4.41) is reported for item 4, which states learners' belief that debate strengthens learners' interaction and ability to share knowledge and success. Omelicheva and Avdeyeva 2008 (604) express that effective learning necessitate engaging learners', "attitudes, feelings, preferences and values". In-class debate can achieve this purpose as it is perceived to be, "an excellent form of active learning" (Fallahi \& Haney, 2007, 83). Active engagement of the learners in the learning process requires developing opportunities for oral interaction (Bellon, 2000). Such opportunities are being furnished by in-class debate, which take the learners to "a new level of skill or learning desired by the instructor" (Firmin, Vaughn \& Dye, 2007, 20). They are effective since they motivate the students to learn (Alford \& Surdu, 2002; Jugdev, Markowski \& Mengel, 2004).

The 2 nd highest mean value is allocated to the item 7 with a mean value of (mean=4.35). The results reveal that in-class debate reinforces active learning by giving the learners control on their own learning. The results of Scott's (2008) research coincide with the findings of the present study which mentions that active learning strategies like debate, discussions, role plays and case studies are preferably utilized by the university teachers. And the ultimate target of such techniques is active learning, which involves the learners in their own learning process. By the same token, Vo \& Morris (2006) discuss that as a supplementary technique debate plays a pivotal role to involve learners in traditional teacher dominated classrooms. In other words, in-class debate is a tool to divorce monotony and passiveness of traditional teacher centered classrooms. In a similar vein, instructor-2 observes that: "A debate either in the EFL classroom or in a public place, demands a systematic, analytical framework and definitely all this consciously or unconsciously develop the skill of arguments and reasoning either they are supporting or opposing something."

In this cluster, the least preference has been attached to the item $5 \& 6$ with similar mean value of (mean=4.29) which indicate that debate process develops learners' patience to accept others' view point as well as enhances their confidence to create arguments, provide evidence and reasoning for it. Similar kinds of findings are received by Fukuda (2003, 417-418), who conducted his study on Japanese learners, claims that before debates $30.8 \%$ learners could confidently express themselves but after using the technique of debate $56.7 \%$ learners started participating and expressing their opinions more vehemently. Likewise, instructor-6 acknowledges that: "In a debate differences are vital otherwise nothing to debate. When a participant puts forward their own opinion either relevant or irrelevant, right or wrong; at the same time others' opinion and ideas should be given due importance. The acceptance or denial of an argument needs to be supported by sufficient reasons otherwise it would be a futile and meaningless practice." The results show that debate enables learners to overcome their hesitation to speak in front of others and inculcate a sense of social responsibility in them. 
Table 5. Saudi EFL learners' opinions about the impacts of in-class debate on their analytical and evaluative skills (HOTs)

\begin{tabular}{|c|c|c|c|c|c|c|c|c|}
\hline S. \# & Statements & Gr. & $\mathrm{N}$ & Range & Min. & Max. & Mean & $\mathrm{SD}$ \\
\hline 7. & $\begin{array}{l}\text { The in-class debate improved my problem-solving skill, } \\
\text { and stimulated my thinking to identify contrasting } \\
\text { arguments on the subject matter. }\end{array}$ & $\mathrm{F}$ & 79 & 4.00 & 1.00 & 5.00 & 4.3644 & 1.00227 \\
\hline 8. & $\begin{array}{l}\text { Working on my own debate and listening to the rest of } \\
\text { the debaters helped me to know the difference between } \\
\text { facts and opinions. }\end{array}$ & $\mathrm{F}$ & 79 & 4.00 & 1.00 & 5.00 & 4.3038 & .85266 \\
\hline 9. & $\begin{array}{l}\text { Preparation and presentation stages of debate inculcated } \\
\text { my ability to create defensive and offensive arguments } \\
\text { and collect evidence and reasoning to support them. }\end{array}$ & $\mathrm{F}$ & 79 & 4.00 & 1.00 & 5.00 & 4.0759 & 1.03493 \\
\hline 10. & $\begin{array}{l}\text { In-class debate enables me to question and probe into } \\
\text { every new and strange phenomenon. }\end{array}$ & $\mathrm{F}$ & 79 & 4.00 & 1.00 & 5.00 & 4.2405 & 1.01546 \\
\hline
\end{tabular}

Table 5 exhibits the results generated from the descriptive analysis of 4 items associated with Taif University's EFL Learners' opinions about the impacts of debate on their analytical and evaluative skills. All the items included in this cluster have obtained highest mean value of more than four. In this cluster, the highly preferred item with mean value of $(m e a n=4.36)$ remains the one, which elicits that debate process improved learners' problem solving skill and ability to identify opposing arguments on the subject matter. The study supports the findings of the work of Silberman (1996), who believes that debate plays pivotal role in the development of learners thinking skill. In a similar vein, the results of the research of Kennedy (2007) highlights that in-class debate develops learners' problem solving skill and ability to evaluate and recognize contrasting opinions. The 2nd highest importance was allocated to the item 8 with mean value of $($ mean $=4.30)$, which shows that practically working on the debate and listening to the debates of other participants enable the learners to understand the difference between facts and opinions. Rashtchi \& Sadraeimanesh (2011) report that language proficiency of the learners could be achieved by organizing debates in the classroom. They believe that learners can achieve mastery of several skills such as critical thinking; problem solving, individual's self-esteem, ability to collaborate and art of speech through in-class debate from preparation to presentation. In this pre-text, instructor-3 highlights that: "Debate is a form of oral controversy that encourages presentation and reception of opposing point of views, goes beyond the exchange of arguments in an effort to build new understanding, mastery of the course content and ability to think critically."

The results reveal that participants have assigned 3rd highest importance to the item 10 with mean value of (mean=4.24), which mentions that in-class debate enables learners to question and probe into every new and strange phenomenon. Likewise, the results of the present study are in-line with the perception of Galloway $(2007,12)$, who believes that through debates: "debaters come to realize that positions other than their own have value and that reasonable minds can disagree on controversial issues". The cohort of this study consider item 9 as the least preferred item with mean value of $($ mean $=4.07)$, which states that preparation and presentation stages of debate inculcate learners ability to create defensive and offensive arguments and collect evidence and reasoning to support them. In this context, instructor-7 expresses that: "In debates, sometimes learners come across with new situations or arguments which have the potential to change the whole paradigm of learners thinking framework. It is said that when we change the way we look at things, the things we look at, get change. Since outward is the reflection and extension of our inward; therefore, at this level learners are open to create an entirely new course of argument or reasoning based on synthesis rather than analysis." Varpio (2018, 2017-210) (Cited in Derouiche, 2019, 30) highlights interesting ideas while discussing the process of developing arguments in the preparation of in-class debate. He believes that while building an argument participants are at liberty to choose the data which captivate audience senses as well as: "appeal to the logic "logos", to authority "ethos" or to emotions "pathos". The results of this cluster strongly reinforce the idea that in-class debate built learners' inquisitive ability, problem solving and argumentation skill through competition. 
Table 6. Saudi EFL learners' opinions about the impacts of in-class debate on their creative and critical thinking skills

\begin{tabular}{|c|c|c|c|c|c|c|c|c|}
\hline S. \# & Statements & Gr. & $\mathrm{N}$ & Range & Min. & Max. & Mean & SD \\
\hline 12. & $\begin{array}{l}\text { The debate process is a tool to involve learners in a fun and } \\
\text { more meaningful ways. }\end{array}$ & $\mathrm{F}$ & 79 & 4.00 & 1.00 & 5.00 & 4.4177 & .87130 \\
\hline 13. & $\begin{array}{l}\text { The debate process boosted my oral communication skill } \\
\text { and creativity. }\end{array}$ & $\mathrm{F}$ & 79 & 4.00 & 1.00 & 5.00 & 4.4177 & .87130 \\
\hline 14. & $\begin{array}{l}\text { The whole process of in-class debate from preparation of } \\
\text { arguments to furnish reasoning and listening to my } \\
\text { opponent's rebuttal evolved my critical thinking skills. }\end{array}$ & $\mathrm{F}$ & 79 & 4.00 & 1.00 & 5.00 & 4.4304 & .88699 \\
\hline
\end{tabular}

Table 6 rakes the result of three items developed from descriptive analysis of the data collected from Taif University's EFL Learners about the impacts of debate on their creative and critical thinking skills. All the items included in this cluster have obtained highest mean value of more than four. An extremely high mean value of (mean=4.43) is reported for item 14, which refers to learners' belief that in-class debate inculcates their argumentation skill, ability to extend and receive denial and henceforth, this practice augment their critical thinking skill. Ramlan et al. (2016) discuss that debate promotes higher order mental abilities of the learners which include ability to think logically, analyze, evaluate, ability to solve the problems and create, which ultimately foster their critical thinking skill. Likewise, Carr $(1998,69)$ reaches at the conclusion that: "Thinking cannot be divorced from content; in fact, thinking is a way of learning content". Furthermore, Worthen \& Pack (1992) reinforce the point that some skills cannot be studied in isolation without their context. By the same token, Sinonneaux (2002) expresses that debate sharpens learners' argumentation skill. In this backdrop, instructor-3 points out that: "A debate help enhances EFL students' curiosity, ability to analyze and confidence to give reasoning. Critical thinking means we don't believe anything blindly instead we go for the interrogation through question such as what, when, where, why, how, who, which, whose, so on and so forth."

In this cluster, items 12 and 13 receive the 2 nd highest mean value of (mean=4.41). Item 12 suggests that the debate activity heavily involves learners in their own learning process through fun and meaningful ways. Oros (2007) explains that debate changes dynamics of the classroom from traditional teacher dominated classrooms to the classrooms, where learners actively participate in the reception and exchange of knowledge and information. Stice $(1987,293)$ (Cited in Smith \& Boyer, 1996) reports that: "students retain 10\% of what they read, $20 \%$ of what they hear, $30 \%$ of what they see, $50 \%$ of what they see and hear, $70 \%$ of what they say, and $90 \%$ of what they do and say together".

In this section, item 13 reinforces that in-class debate fosters active-learning, which has an ultimate target to trigger critical thinking skill by focusing on oral communication, collaboration, and creativity. The findings of the present study coincide with the result of Roy \& Macchiette (2005) (Cited in Derouiche 2019, 32), which reinforce that debate process generates participants' creativity and motivates them to think not only, what should be expressed but also how it should be expressed. To the same idea Bonwell \& Eison $(1991,2)$ elaborate in this way that: "anything that involves students doing things and thinking about the things they are doing" is active-learning. By the same token, instructor-1 believes that: "Debate significantly improves the EFL learners' critical thinking and speaking skill achievements and contributes to each aspect of critical thinking and speaking skill, such as fluency, grammar, pronunciation, comprehension, and vocabulary." Zare, \& Othman (2013) explain that debate is an effective and authentic strategy which encourages the learners of different cultures to collaborate and cooperate in problem solving and asking questions. Likewise, several studies indicate that learners who practice debate in the classroom are different from those who learn individually. They believe that in-class debate fosters learners' self-esteem and confidence and promotes their motivation, memorization and critical thinking skill. Similarly, they contend that cooperative learning improves learners' problem-solving skill as learners are exposed to the diverse perspectives of a given situation (Darby, 2007; Jugdev, Markowski, \& Mengel, 2004; Oros, 2007; Bruner, 1985). In a similar vein, Vygotsky (1978) comments that collaborative activities enable learners to perform at highest intellectual level and retain information for a longer period of time than working individually. In this pretext, instructor-5 mentions that: "The correlation between debate and speaking skills is very strong and one aspect that was most influenced by debate is fluency. This may be the result of debate process itself in which the students deliver and defend their own arguments as well as oppose the opponent's ideas and arguments." The findings of this cluster indicate that in-class debate emphasizes highly on oral communication, collaboration and in-depth mastery of the course content and through these channels invoke learners' creativity and critical thinking skills which in the context of present scenario are perceived as the core 
essence of success in all the professions.

\section{Recommendations}

Considering the fact that in-class debates cultivate active engagement of the learners, place responsibility of their own learning and provides opportunity to speak, listen, read, write and reflect on the course content more effectively. After analyzing the data collected from the participants of the study, following recommendations have been designed.

1) The university should encourage instructors to utilize this cooperative and collaborative enterprise in an organized format by assigning the learners specific roles, such as: "debaters facilitate significantly different communicative process; moderator acts as a referee; convener set rules and purpose of debate, and audience actively and critically participate...", to internalize the course content and achieve maximum benefits in the classroom (Busmek, 2009) (Cited in Salim, 2015, 98).

2) Debate is a useful in-class strategy that stacks several skills in one bundle. Snider \& Schnurer (2002) remark that in-class debate is one among those methods that clump multiplicity of skills together, such as; active learning, social responsibility, critical thinking, cooperative learning, strategic note-taking, logical organization, critical reading, evaluation and communication skill.

3) The teachers may organize 'Four-Corner Debate Model' to elicit different responses and reactions from the learners. This model requires labeling of four corners of the classroom, for instance; a. 'strongly agree', $b$. 'agree', c. 'disagree', d. 'strongly disagree', and learners are required to choose any one among them according to their opinion about the topic of debate (Hopkins, 2003).

4) In order to expose the learners to new perspectives and stop treading the beaten tracks, each learner should be assigned the task to defend one position during the debate and another in a written assignment (Budesheim, \& Lundquist, 2000). This provides the learners a very positive learning experience, when they support opposite view point of their personal opinion. In-line with this is the idea recommended by Keller, Whittaker, \& Burke, (2001), who suggest that interchanging the position from positive to negative and vice versa engenders vivid impacts on learners shifting perspectives on a given topic.

5) In-class debate is an important educational tool utilized to boost learners' analytical skills, evaluation, understanding and in-depth reflection on any given perspective. By keeping in view such wide-ranging benefits, it is strongly recommended that in-class debate should be embedded in the curriculum since it's a significant tool to reinforce learners' critical thinking skill. In this context, Bellon $(2000,161)$ expresses that, "those of us who have witnessed the power of debate to enhance learning and motivate students are becoming advocates of instituting debate across the entire college curriculum".

Last but not least, for a successful in-class debate, it is significant that activity should follow a certain format and instructor should grade the debaters cum non-debaters according to a particular rubric. Moeller (1985) (Cited in Salim, 2015), who marked his learners based on their individual and team performance; therefore, formulated rubric for both, as for instance; performance indicators for individuals include: "diction, eye contact, insight into the issue and overall effectiveness," and performance indicators for team are: "organization, preparation, use of supporting evidence and use of rebuttal". Both the categories of learners must be assigned specific activities to keep pace with the learning objectives.

\section{Conclusion}

Overall results of the study show that learners have indicated their high satisfaction towards the items investigated in the survey. The first research question envisaged for the study emphasizes that, 'How does in-class debate play a pivotal role in the development of learners' critical thinking skill?' The findings indicate that participants reported highest preference for this cluster (table-5 \& 6) with mean value of (mean=4.24-43), which mentions that in-class debate from preparation to presentation my ability of problem solving, inquisitive probing, evaluating and critically analyzing every phenomenon have enormously been sparked. It's an established fact, that students learn effectively when they are actively engaged and apply the content in a meaningful way in learner centered activities instead of receiving the information passively. It's also beyond doubt that learners get benefit from active instructional strategies that engage them in discussion, analysis and application of the course content. In this context, Carini, Kuh, and Klein (2006) note that the essence of learners' critical thinking is in their active engagement in collaborative activities. Apart from active engagement and mastery of the course content, in-class debate serves enormous benefits to the learners. The strategy requires the participants to actively listen and evaluate the competing point of views that ultimately generate their higher-order psychological processing, which according to Vygotskean model results from social interaction and 
in Bloom's taxonomy ignites through collaborative interaction.

The second question formulated for the study is, 'How does in-class debate trigger learners' collaborative and communicative faculties?' The participants reported highest preference for this variable (table-4) with mean value of (mean=4.29-41), which highlights that in-class debate fosters collaboration and teamwork by engaging the learners in discussions and provides them an opportunity to take responsibility of their own learning. Bonwell \& Eison (1991) (Cited in Kennedy, 2007) note that the use of in-class debate actively engages learners in their classroom learning. Similarly, the studies which emphasized the importance of in-class debate in higher education perceive it a collaborative strategy (Frijters et al., 2006; Oros, 2007). It appears from the findings of the existing research that collaboration is intrinsically linked with the communication which ultimately enhances personal and collective knowledge of the participants. The preparation and exchange of arguments in which two opposing teams defend and attack a given proposition deeply engage participants in social interaction and confer them control on their own learning. In-class debate provides a viable means of incorporating discussions regarding real-life situations which revolve around change of learners' opinions, their tolerance of opposing ideas and finally inculcate compromises. Such real life-like situations can only be incorporated in the curriculum through the strategy of in-class debate. Williams, McGee, \& Worth (2001) investigated 286 participants of competitive debate teams at 70 different universities. These learners highlighted that in-class debate polished their communication skill at maximum. Similarly, Combs and Bourne (1994) survey marketing students and observe significant changes in their oral communication as an outcome of in-class debate. The findings of the study of Dundes (2001) (Cited in Kennedy, 2007) report that after a debate competition her learners, in Criminal Justice course at Western Maryland College, were likely to express their opinion in the class, who initially couldn't speak.

The third question proposed for the work in hand investigates significance of the in-class debate in the EFL learners' mastery of the course content. The participants of the present study report high preference for the items of this cluster (table-3) with mean value of (mean=4.39-48). It's a well-accepted fact that the fun activities captivate learners' attention, boost their motivation and heighten their understanding of the course content. Similar is the case of in-class debate, which invokes learners' interest with the incentive to score more, take a win over their opponents, capture their interest and curiosity and ultimately deepen their understanding. Such activities enhance learning and understanding of the subject matter. This leads the researchers to claim that in-class debate is an active learning strategy that engages learners' concentration in the classroom (Kennedy, 2007, 2009) and empirical research shows that interactive activities help develop learners' content mastery (Goodwin, 2003) (Cited in el Majidi, de Graaff, \& Janssen, 2015). The cognitive research shows that successful classrooms are interactive that helps in cultivating the culture of open-mindedness and acceptance of several views on a given topic (Bellon, 2000; Kennedy, 2007). In nutshell, the present inquiry figures out learners' responses and reactions towards the impacts of in-class debate on their content mastery, collaborative, communicative and critical thinking enterprises coupled with highlights that it doesn't only ignite learners' ability of 'what to say', and 'how to say' but also 'why to say', 'when to say' and 'whom to say'.

\section{References}

Adler, M. J. (1982). The Paideia proposal: An education manifesto. New York, NY: Macmillan.

Al Zahrani, B. S., \& Elyas, T. (2017). The implementation of critical thinking in a Saudi EFL context: Challenges and opportunities. Indonesian Journal of English Language Teaching and Applied Linguistics, 1(2), 133-141. https://doi.org/10.21093/ijeltal.v1i2.21

Alasmari, A., \& Ahmed, S. (2013). Using Debate in EFL Classes. English Language Teaching, 6(1), 147-152. https://doi.org/10.5539/elt.v6n1p147

Alén, E., Domínguez, T., \& de Carlos, P. (2015). University students' perceptions of the use of academic debates as a teaching methodology. Journal of Hospitality, Leisure, Sport \& Tourism Education, 16, 15-21. https://doi.org/10.1016/j.jhlste.2014.11.001

Alford, K. L., \& Surdu, J. R. (2002). Using in-class debates as a teaching tool. Paper presented in 32nd Frontiers in Education Conference, Boston, ASEE/IEEE, 3, S1F-S1F. https://doi.org/10.1109/FIE.2002.1158634

Allamnakhrah, A. (2013). Learning critical thinking in Saudi Arabia: Student perceptions of secondary pre-service teacher education programs. Journal of Education and Learning, 2(1), 197-210. https://doi.org/10.5539/jel.v2n1p197

Alsaleh, N. J. (2020). Teaching Critical Thinking Skills: Literature Review. Turkish Online Journal of Educational Technology, 19(1), 21-39. Retrieved from http://www.tojet.net 
Alwadai, M. A. (2014). Islamic Teachers' Perceptions of Improving Critical Thinking Skills in Saudi Arabian Elementary Schools. Journal of Education and Learning, 3(4), 37-48. http://dx.doi.org/10.5539/jel.v3n4p37

Alwehaibi, H. (2012). Novel program to promote critical thinking among higher education students: Empirical Study from Saudi Arabia. Asian Social Science, 8(11), 193. https://doi.org/10.5539/ass.v8n11p193

Anderson, T., \& Soden, R. (2001). Peer interaction and the learning of critical thinking skills. Psychology Learning and Teaching, 1(1), 37-40. https://doi.org/10.2304/plat.2001.1.1.37

Anderson, T., Howe, C., Soden, R., Halliday, J., \& Low, J. (2001). Peer interaction and the learning of critical thinking skills in further education students. International Science, 29(1), 1-32. https://doi.org/10.1023/A:1026471702353

Beck, C. (1999). Francine, kerplunk, and the golden nugget-Conducting mock trials and debates in the classroom. Social Studies, 90(2), 78-84. https://doi.org/10.1080/00377999909602395

Bellon, J. (2000). A research-based justification for debate across the curriculum. Argumentation and Advocacy, 36(3), 161-175. https://doi.org/10.1080/00028533.2000.11951646

Bonwell, C. C. (1996). Enhancing the lecture: revitalizing a traditional format. In T. E. Sutherland \& C. C. Bonwell (Eds.), Using active learning in college classes: A range of options for faculty. New Directions for Teaching and Learning, 67, 31-44. San Francisco, CA: Jossey-Bass. https://doi.org/10.1002/tl.37219966706

Bonwell, C. C., \& Eison, J. A. (1991). Active Learning: Creating Excitement in the Classroom. 1991 ASHE-ERIC Higher Education Reports. ERIC Clearinghouse on Higher Education, The George Washington University, One Dupont Circle, Suite 630, Washington, DC 20036-1183. Retrieved from https://eric.ed.gov/?id=ED336049

Brown, Z. (2015). The use of in-class debates as a teaching strategy in increasing students' critical thinking and collaborative learning skills in higher education. Educational Futures, 7(1), 39-55. Retrieved from http://hdl.handle.net/2436/621883

Budesheim, T., \& Lundquist, A. (2000). Consider the opposite: Opening minds through in-class debates on course-related controversies. Teaching of Psychology, 26(2), 106-110. https://doi.org/10.1207/s15328023top2602_5

Busmek, P. (2009). Debate as Disease: Debate and the Dialogue and Deliberation Movement. Contemporary Argumentation and Debate, 30(1), 1-29.

Camp, J. M., \& Schnader, A. L. (2010). Using debate to enhance critical thinking in the accounting classroom: The Sarbanes-Oxley Act and U.S. tax policy. Issues in Accounting Education, 25(4), 655-675. https://doi.org/10.2308/iace.2010.25.4.655

Carini, R., Kuh, G., \& Klein, S. (2006). Student engagement and student learning: Testing the linkages. Research in Higher Education, 47(1), 1-32. https://doi.org/10.1007/s11162-005-8150-9

Chance, P. (1986). Thinking in the Classroom: A Survey of Programs. Teachers College Press, 1234 Amsterdam Ave., New York, NY 10027. Retrieved from https://eric.ed.gov/?id=ED269235

Choque, K., \& Mouraz, A. (2015). Debate as a practice in Higher Education curricula (pp. 191-199). Curriculum studies: policies, perspectives and practices. Retrieved from https://repositorio-aberto.up.pt/bitstream/10216/81905/2/108851.pdf

Combs, H., \& Bourne, S. (1994). The renaissance of educational debate: Results of a five-year study of the use of debate in business education. Journal on Excellence in College Teaching, 5(1), 57-67. Retrieved from https://eric.ed.gov/?id=EJ505291

Corson, D. (1988). Oral language across the curriculum. Philadelphia: Multilingual Matters Ltd. Retrieved from https://books.google.com.sa/books?

Cronin, M., \& Glenn, P. (1991). Oral Communication Across the Curriculum in Higher Education: The State of

Darby, M. (2007). Debate: A teaching-learning strategy for developing competence in communication and critical thinking. vAmerican Dental Hygienists' Association, 81(4), 1-10. Retrieved from https://jdh.adha.org/content/jdenthyg/81/4/78.full.pdf

Dobson, M. J. (1987). Effective techniques for English conversation groups. Washington, D. C.: United States Information Agency. 
Doody, O., \& Condon, M. (2012). Increasing student involvement and learning through using debate as an assessment. Nurse Education in Practice, 12(4), 232-237. https://doi.org/10.1016/j.nepr.2012.03.002

Dundes, L. (2001). Small group debates: Fostering critical thinking in oral presentations with maximal class involvement. Teaching Sociology, 29(2), 237-243. https://doi.org/10.2307/1318721

el Majidi, A., de Graaff, R., \& Janssen, D. (2015). Invest in what energizes students to learn: Investigating students' attitude towards debate in the foreign language classroom. Journal of Language Teaching and Research, 6(5), 924-932. https://doi.org/10.17507/jltr.0605.03

Ennis, R. H. (1993). Critical thinking assessment. Theory into Practice, 32(3), 179-186. https://doi.org/10.1080/00405849309543594

Fallahi, C. R., \& Haney, C. R. (2007). Using debate in helping students discuss controversial topics. Journal of College Teaching \& Learning, 4(10), 83-88. https://doi.org/10.19030/tlc.v4i10.1540

Firmin, M., Vaughn, A., \& Dye, A. (2007). Using debate to maximize learning potential: A case study. Journal of College Teaching \& Learning, 4(1), 19-31. https://doi.org/10.19030/tlc.v4i1.1635

Freeley, A., \& Steinberg, D. (2005). Argumentation and debate: Critical thinking for reasoned decision making (11th ed.). Belmont, CA: Wadsworth.

Frijters, S., Dam, G., \& Rijlaarsdam, G. (2006). Effects of dialogic learning on value loaded critical thinking. Learning and Instruction, 18(1), 66-82. https://doi.org/10.1016/j.learninstruc.2006.11.001

Gashan, A. K. (2015). Exploring Saudi pre-service teachers' knowledge of critical thinking skills and their teaching perceptions. International Journal of Education and Literacy Studies, 3(1), 26-33. https://dx.doi.org/10.7575/aiac.ijels.v.3n.1p.26

Gaskaree, B. L., Mashhady, H., \& Dousti, M. (2010). Using critical thinking activities as tools to integrate language skills. Sino-US English Teaching, 7, 33-45.

Gieve, S. (1998). Comments on Dwight Atkinson's A critical approach to critical thinking in TESOL. TESOL Quarterly, 32(1), 123-129. https://doi.org/10.2307/3587907

Goodwin, J. (2003). Students' perspectives on debate exercises in content area classes. Communication Education, 52(2), 157-163. https://doi.org/10.1080/03634520302466

Guiller, J., Durndell, A., \& Ross, A. (2008). Peer interaction and critical thinking: Face-to-face or online discussion? Learning and Instruction, 18(2), 187-200. https://doi.org/10.1016/j.learninstruc.2007.03.001

Hasibuan, A. L., \& Batubara, I. A. (2012). Implementing problem-based learning in digitalization era through debating practice (pp. 13-30). Proceedings of the 59th TEFLIN International Conference. Surabaya: Widya Mandala Catholic University.

Heining-Boynton, A. L., \& Heining-Boynton, D. B. (1992). Incorporating higher-order thinking skills in the foreign language curriculum. In R. M. Terry (Ed.), Foreign Languages: Internationalizing the future: Dimension: Language '92-'93 (pp. 69-83). Valdosta, GA: Southern Conference on Language Teaching.

Hill, B. (1982). Intercollegiate debate: Why do students bother? Southern Speech Communication Journal, 48(1), 77-88. https://doi.org/10.1080/10417948209372554

Hoch, F. S., \& Hart, T. (1991). Infusing critical and creative thinking skills into the foreign language classroom. In R. M. Terry (Ed.), Making a world of difference: Dimension: Language, 91(pp. 33-39). Valdosta, GA: Southern Conference on Language Teaching.

Hopkins, G. (2003). Four corner debate. Retrieved April 21, 2020, from http://www.educationworld.com/a_lesson/03/lp304-04.shtml

Huryn, J. S. (1986). Debating as a teaching technique. Teaching Sociology, 14(4), 266-269. https://doi.org/10.2307/1318385

Iman, J. N. (2017). Debate Instruction in EFL Classroom: Impacts on the Critical Thinking and Speaking Skill. International Journal of Instruction, 10(4), 87-108. https://doi.org/10.12973/iji.2017.1046a

Jackson, M. (2009). Debate: A neglected teaching tool. Peabody Journal of Education, 50(2), 150-154. https://doi.org/10.1080/01619567309537903

Jagger, S. (2013). Affective learning and the classroom debate. Innovation in Education and Teaching International, 50(1), 38-50. https://doi.org/10.1080/14703297.2012.746515 
Javid, C., \& Umer, M. (2014). Saudi EFL learners' writing problems: a move towards solution (pp. 4-5). Proceedings from GSE 2014: The Global Summit on Education. Retrieved from https://www.worldconferences.net/proceedings/gse2014/toc/papers_gse2014/

Jugdev, K., Markowski, C., \& Mengel, T. (2004). Using the debate as a teaching tool in the online classroom. Online Classroom, 4-7. $\quad$ Retrieved from https://auspace.athabascau.ca/bitstream/handle/2149/281/2004\%20online?sequence=1

Kegley, M. (2014). Debating as a Team Learning Strategy in an Economics Classroom. AURCO Journal: Association for University Regional Campuses of Ohio, 20, 1-15. Retrieved May 12, 2020, from http://www.aurco.org/Journals/AURCO_Journal_2014/Debating_Michele_Kegley_AURCO_Vol20_2014.p $\mathrm{df}$

Keller, T., Whittaker, J., \& Burke, T. (2001). Student debates in policy courses: Promoting policy practice skills and knowledge through active learning. Journal of Social Work Education, 37(2), 343-355. https://doi.org/10.1080/10437797.2001.10779059

Kennedy, R. (2007). In-class debates: Fertile ground for active learning and the cultivation of critical thinking and oral communication skills. International Journal of Teaching and Learning in Higher Education, 19(2), 183-190. Retrieved from http://www.isetl.org/ijtlhe/

Kosciulek, J. F., \& Wheaton, J. E. (2003). On critical thinking. Rehabilitation Education, 17(2), 71-79. Retrieved from https://psycnet.apa.org/record/2003-08103-001

Kurniawan, R. (2013). Applying debate method in EFL classroom. Journal of English and Arabic Language Teaching, 4(1), 21-33. Retrieved from http://ejournal.uin-suska.ac.id/index.php/jealt/article/view/43/33

Landrum, R. (1991). Student evaluation of classroom debates. College Student Journal, 25(2), 163-165. Retrieved from https://ericlandrum.com/s/Student-evaluation-of-classroom-debates-Landrum-1991.pdf

Lantis, J. S. (2004). Ethics and foreign policy: structured debates for the international studies classroom. International Studies Perspectives, 5(2), 117-133. https://doi.org/10.1111/j.1528-3577.2004.00162.x

Lantolf, J. P. (2002). Commentary from the flower garden: Responding to Gregg 2000. Second Language Research, 18(1), 72-78. https://doi.org/10.1191/0267658302sr198xx

Lieb, M. (2007). Teaching Debate Skills to Intermediate and Lower Level EFL Students. Retrieved from http://www.tht-japan.org/proceedings/2007/m_lieb73-84.pdf.

Lipman, M. (1988). Critical thinking-what can it be? Educational Leadership, 46(1), 38-43. Retrieved from https://files.eric.ed.gov/fulltext/ED352326.pdf

Malone, Y., \& Michael, T. (2018). Collaborative learning and critical thinking skills: Effects of a debate-based pedagogy. International Journal of Learning and Teaching, 10(1), 61-69. https://doi.org/10.18844/ijlt.v10i1.3146

Mitchell, G. (1998). Pedagogical possibilities for argumentative agency in academic debate. Argumentation \& Advocacy, 35(2), 41-60. https://doi.org/10.1080/00028533.1998.11951620

Moeller, T. (1985). Using classroom debates in teaching Developmental Psychology. Teaching of Psychology, 12(4), 207-209. https://doi.org/10.1207/s15328023top1204_5

Moore, K. G., Clements, J., Sease, J., \& Anderson, Z. (2015). The utility of clinical controversy debates in an ambulatory care elective. Science Direct, 7, 239-248. https://doi.org/10.1016/j.cptl.2014.11.020

Munakata, M. (2010). The mathematics education debates: Preparing students to become professionally active mathematics teachers. Primus, 20(8), 712-720. https://doi.org/10.1080/10511970902870372

Newmann, F. M., \& Wehlage, G. G. (1995). Successful school restructuring: A report to the public and educators by the Center on Organization and Restructuring of Schools. Madison, WI: Center on Organization and Restructuring of Schools. Retrieved from https://files.eric.ed.gov/fulltext/ED387925.pdf

Ng, P. T., Lan, L. K. Y., \& They, J. T. E. (2004). Developing reflective teachers: The experience of two modules in the teacher training programme at the National Institute of Education, Singapore. Asia Pacific Education Review, 5(2), 200-206. https://doi.org/10.1007/BF03024957

Norris, S. P. (1985). Synthesis of Research on Critical Thinking. Educational Leadership, 42(8), 40-45. Retrieved from https://eric.ed.gov/?id=EJ319814

Omelicheva, M. Y., \& Avdeyeva, O. (2008). Teaching with lecture or debate? Testing the effectiveness of 
traditional versus active learning methods of instruction. PS: Political Science \& Politics, 41(3), 603-607. https://doi.org/10.1017/S1049096508080815

Oros, A. (2007). Let's Debate: Active Learning Encourages Student Participation and Critical Thinking. Journal of Political Science Education, 3(3), 293-311. https://doi.org/10.1080/15512160701558273

Osborne, A. (2005). Debate and student development in the history classroom. New Directions for Teaching and Learning, 2005(103), 39-50. https://doi.org/10.1002/tl.202

Othman, M., Sahamid, H., Zulkefli, M., Hashim, R., \& Mohamad, F. (2015). The effects of debate competition on critical thinking among Malaysian second language learners. Middle-East Journal of Scientific Research, 23(4), 656-664.

Parcher, J. (1998). The value of debate: Adapted from the report of the Philodemic Debate Society. US: Georgetown University. Retrieved April 21, 2020, from http://www.tmsdebate.org/main/forensics/snfl/debate_just2.htm

Paul, R., \& Elder, L. (2007). Critical Thinking: The Art of Socratic Questioning. Journal of Developmental Education, 31(1), 36-37. Retrieved from https://search.proquest.com/openview/ab8902a8099e51ff3874487ea300bea8/1?

Paulette, D., \& Wolf, J. C. (2000). Speech communication made simple (2nd ed.). NY: Addison Wesley Longman. Retrieved

from http://www.normadiconline.com/speech/speech-communication-made-simple-a-multicultural-perspective.p $\mathrm{df}$

Pezhman, Z., \& Moomala, O. (2015). Students' Perceptions toward Using Classroom Debate to Develop Critical Thinking and Oral Communication Ability. Asian Social Science, 11(9), 158-170. https://doi.org/10.5539/ass.v11n9p158

Phajoohande, M. H. (2001). Education Efficient in Islamic Culture. Journal of Philosophy and Mysticism, 29, August and September.

Rahimi, S. S. (2009). An Improved Method for Dynamic Collaborative Learning in University. Journal of Educational Technology, 3(3), 171-178.

Rashtchi, M., \& Sadraeimanesh, F. (2011). Is debate a useful strategy in enhancing the reading comprehension and critical thinking of Iranian EFL learners? Theory and Practice in Language Studies, 1(4), 361-369. https://doi.org/10.4304/tpls.1.4.361-369

Resnick, L. (1989). In L. Resnick \& L. Klopfer (Eds.), Toward the thinking curriculum: An overview. Pittsburg: ASCD Yearbook.

Resnick, L. B., \& Klopfer, L. E. (1989). Toward the Thinking Curriculum: Current Cognitive Research. 1989 ASCD Yearbook. Association for Supervision and Curriculum Development, 1250 N. Pitt St., Alexandria, VA 22314-1403. Retrieved from https://eric.ed.gov/?id=ed328871

Rowland, R. (1995). The practical pedagogical function of academic debate. Contemporary Argumentation \& Debate, 16, 98-108. Retrieved from http://www.cedadebate.org/cad/index.php/CAD/article/view/200/185

Roy, A., \& Maechiette, B. (2005). Debating the issues: A tool for augmenting critical thinking skills of marketing students. Journal of Marketing Education, 27(3), 264-276. https://doi.org/10.1177/0273475305280533

Rudd, D. (2007). Defining critical thinking. Techniques (ACTE), 82(7), 46-49.

Ryan, S., \& College, B. (2006). Arguing toward a more active citizenry: Re-envisioning the introductory civics course via debate-centered pedagogy. Journal of Public Affairs Education, 12(3), 385-395. https://doi.org/10.1080/15236803.2006.12001442

Rybold, G. (2006). Speaking, Listening and Understanding: debate for non-native English speakers. New York: IDEA. Retrieved from https://books.google.com.sa/books?

Salim, A. (2015). Debate as a learning teaching method: A survey of literature. TARBIYA: Journal of Education in Muslim Society, 2(1), 97-104. https://doi.org/10.15408/tjems.v2i1.1665

Scannapeico, F. (1997). Formal debate: An active learning strategy. Journal of Dental Education, 61, 995-996. https://doi.org/10.1111/j.1600-0579.2006.00390.x

Scott, S. (2008). Perceptions of students' learning critical thinking through debate in a technology classroom: A case study. The Journal of Technology Studies, 34(1), 39-44. https://doi.org/10.21061/jots.v34i1.a.5 
Snider, A., \& Schnurer, M. (2002). Many sides: Debate across the curriculum. New York: International Debate Education Association. Retrieved from https://books.google.com.sa/books?

Steinfatt, T. (1986). Communication Across the Curriculum. Communication Quarterly, 34(4), 460-470. https://doi.org/10.1080/01463378609369663

Sternberg, R. J. (1986). Critical thinking: Its nature, measurement, and improvement. New Haven, CT: Yale University. Retrieved from https://eric.ed.gov/?id=ED272882

Stewart, T., \& Gene, P. (1998). Developing Academic Language Skills and Fluency through Debate. The Language Teacher, 22(10), 27-32. $\quad$ Retrieved from http://www.jalt-publications.org/ttt/files/98/oct/stewart.html.

Suhailah, H. (2001). Teachers' perception of the teaching of thinking and their practices in secondary schools in Klang, Selangor. Unpublished Master Dissertation. International Islamic University Malaysia, Gombak.

Temple, M. (1997). Using debate to develop health literacy. Journal of School Health, 67(3), 116-117. https://doi.org/10.1111/j.1746-1561.1997.tb03427.x

Tessier, J. T. (2009). Classroom debate format effect on student learning and revelations about student tendencies. College Teaching, 57(3), 144-152. https://doi.org/10.3200/CTCH.57.3.144-152 the Art. Communication Education, 40(4), 356-367. https://doi.org/10.1080/03634529109378860

Varpio, L. (2018). Using rhetorical appeals to credibility, logic, and emotions to increase your persuasiveness. Perspectives on Medical Education, 7(3), 207-210. https://doi.org/10.1007/s40037-018-0420-2

Wiggins, S., \& Forrest, S. (2005). Integrating quantitative and qualitative approaches in psychology research methods teaching: The example of a classroom debate. Psychology Learning \& Teaching, 4(2), 90-94. https://doi.org/10.2304/plat.2004.4.2.90

Williams, D. E., McGee, B. R., \& Worth, D. S. (2001). University student perceptions of the efficacy of debate participation: An empirical investigation. Argumentation and Advocacy, 37(4), 198-209. https://doi.org/10.1080/00028533.2001.11951670

Williams, M., Lively, M., \& Harper, J. (1994). Higher order thinking skills: Tools for bridging the gap. Foreign Language Annals, 27(3), 405-426. https://doi.org/10.1111/j.1944-9720.1994.tb01217.x

Woude, N. V. D., Janssen, D., \& Sanders, T. (2011). Flywheel forensics: Debat en public speaking in de klas. Levende Talen Magazine, 98(8), 4-9. Retrieved from http://lt-tijdschriften.nl/ojs/index.php/ltm/article/viewFile/53/53

Yang, C., \& Rusli, E. (2012). Using Debate as a Pedagogical Tool in Enhancing Pre-service Teachers' Learning and Critical Thinking. Journal of International Education Research, 8(2), 135-144. https://doi.org/10.19030/jier.v8i2.6833

Zare, P., \& Othman, M. (2013). Classroom debate as a systematic teaching/learning approach. World Applied Sciences Journal, 28(11), 1506-1513.

\section{Copyrights}

Copyright for this article is retained by the author, with first publication rights granted to the journal.

This is an open-access article distributed under the terms and conditions of the Creative Commons Attribution license (http://creativecommons.org/licenses/by/4.0/). 